\title{
Polyamines accentuate vase life by augmenting antioxidant system in cut spikes of Consolida ajacis (L.) Schur.
}

\author{
Aehsan ul Haq ${ }^{1}\left(\mathbb{D}\right.$, Sumira Farooq ${ }^{1}\left(\mathbb{D}\right.$, Mohammad Lateef Lone ${ }^{1}\left(\mathbb{D}\right.$, Shazia Parveen ${ }^{1}(\mathbb{D}$, \\ Foziya Altaf ${ }^{1} \mathbb{D}$, Inayatullah Tahir $^{1 *}$ (1)
}

${ }^{1}$ University of Kashmir, Department of Botany, Plant Physiology and Biochemistry Research Laboratory, Hazratbal, Srinagar, India.

\begin{abstract}
Postharvest senescence is one of the crucial challenges limiting the marketability of cut flowers. Pertinently, recent investigations implicate extensive role of polyamines in regulation of flower senescence. The present study was envisaged to test the efficacy of poylamines in preserving the postharvest quality of Consolida ajacis (C. ajacis) cut spikes. The cut spikes of $C$. ajacis were subjected to various treatments of polyamines viz, $4 \mathrm{mM}$ Spermine (SPM), 6mM Putrescine (PUT) and $6 \mathrm{mM}$ Spermidine (SPD). A separate set of spikes held in distilled water represented the control. Our results authenticate a significant improvement in vase life of cut spikes of $C$. ajacis as compared to control. The increment in vase life was commensurate with the higher concentration of sugars, proteins and phenols in the tepal tissues. Polyamines amplified the activity of various antioxidant enzymes viz, superoxide dismutase (SOD), catalase (CAT) and ascorbate peroxidase (APX) to overcome the deleterious effects of reactive oxygen species (ROS). The membrane outflow of tepal tissues was profoundly reduced due to attenuated lipoxygenase (LOX) activity. These findings reveal conspicuous role of polyamines particularly SPM in modulation of flower senescence in cut spikes of $C$. ajacis. Keywords: antioxidant enzymes, putrescine, spermidine, spermine, sugars, vase life.
\end{abstract}

\section{Resumo}

Poliaminas aumentam a vida de vaso pelo estímulo do sistema antioxidante em inflorescências de corte de Consolida ajacis (L.) Schur

A senescência pós-colheita é um dos desafios cruciais que limitam a comercialização das flores de corte. Pertinentemente, investigações recentes relacionam um extenso papel das poliaminas na regulação da senescência das flores. O presente estudo foi planejado para testar a eficácia das poliaminas na preservação da qualidade pós-colheita de inflorescências cortadas de Consolida ajacis (C. ajacis). As inflorescências de $C$. ajacis foram submetidas a vários tratamentos de poliaminas, a saber, $4 \mathrm{mM}$ de espermina (SPM), 6 mM de Putrescina (PUT) e $6 \mathrm{mM}$ de espermidina (SPD). Um conjunto separado de inflorescências foi mantido em água destilada para o controle. Os resultados demonstraram uma melhoria significativa na vida de vaso das inflorescências cortadas de $C$. ajacis em comparação com o controle. O incremento na vida de vaso foi proporcional à maior concentração de açúcares, proteínas e fenóis nos tecidos das tépalas. As poliaminas promoveram a atividade de várias enzimas antioxidantes viz, superóxido dismutase (SOD), catalase (CAT) e ascorbato peroxidase (APX) para superar os efeitos deletérios das espécies reativas de oxigênio (ROS). O fluxo de saída da membrana dos tecidos das tépalas foi intensamente reduzido devido à atividade atenuada da lipoxigenase (LOX). Esses resultados revelam o importante papel das poliaminas, particularmente SPM, na modulação da senescência da flor em inflorescências de corte de C. ajacis.

Palavras-chave: Enzimas antioxidantes, putrescina, espermidina, espermina, açúcares, vida de vaso.

\section{Introduction}

Provocation of precocious postharvest senescence is a key bottleneck in the marketing of cut flowers (Sedaghathoor et al., 2020). Consequently, suitable postharvest treatments need to be developed for their efficient marketability (Rabiza-Świder et al., 2020). Postharvest longevity is an important trait for customer satisfaction as the flowers with increased longevity fetch higher price in the market (Ha et al., 2017; Vehniwal and Abbey, 2019). The process of flower senescence is regulated by interplay of several growth regulators viz. ethylene, jasmonic acid, salicylic acid (SA), abscisic acid (ABA), brassinosteroids, cytokinins, gibberellic acid (GA) and auxins (Iqbal et al., 
2017). Among these, ethylene is regarded as key player in regulating senescence in ethylene responsive flowers with, little or no role in ethylene insensitive flowers (Nisar et al., 2015; Ma et al., 2018). C. ajacis is an important ornamental plant of the family Ranunculaceae producing ravishing spikes of various hues and colors. It is highly responsive to ethylene which provokes its early senescence (Shahri et al., 2011). Typical symptoms of senescence in C. ajacis flowers include wilting followed by abscission of tepals. Although, several anti-ethylene treatments have been tried in mitigating postharvest senescence in cut spikes of $C$. ajacis (Shahri and Tahir, 2010), but the efficacy of polyamines has not been probed so far in improving postharvest performance of cut spikes of $C$. ajacis. The common polyamines found in the plants include, Spermine, Putrescine and Spermidine. The process of senescence is essentially regulated by interplay between ethylene and polyamines. Generally, ethylene and polyamines have antagonistic roles in relation to flower senescence due to their competition for the common precursor, S-adenosyl methionine (SAM) (Davarynejad et al., 2021). Polyamines are purported as effective anti-senescence chemicals with convincing role in regulation of senescence as observed in Rosa and Gerbera (Vieira et al., 2017; Ghorbani et al., 2018). Polyamines improve vase life by reducing ethylene output, respiratory rate and color fading of petals (Tiburcio et al., 2014; Karimi et al., 2017). Exogenous inclusion of polyamines mitigate postharvest senescence by improving sugar content and up regulating antioxidant responses as evident in Chrysanthemum and Lisianthus cut flowers (Kandil et al., 2011; Ataii et al., 2015). In addition, polyamines are also known to prolong flower longevity by reducing membrane seepage thereby conferring membrane stability (Sedaghathoor et al., 2020). In view of the convincing evidence of polyamines in senescence regulation, the current study was devised to explicate the efficacy of polyamines in alleviating postharvest senescence in cut spikes of $C$. ajacis.

\section{Material and methods}

\section{Plant material}

Uniform spikes of $C$. ajacis were harvested at 1-2 floret open stage at 8:00 h. from healthy plants growing in Kashmir University Botanical Garden. Harvested spikes were immediately transferred to laboratory, defoliated and trimmed to a uniform length of $30 \mathrm{~cm}$ under water to avoid embolism. The spikes were later placed in $100 \mathrm{~mL}$ Erlenmeyer flasks containing a range of concentrations viz, $2 \mathrm{mM}, 4 \mathrm{mM}, 6 \mathrm{mM}$ and $8 \mathrm{mM}$ of different polyamines (SPM, PUT and SPD). A separate set of spikes designated as control were held in distilled water. Each treatment including control had 10 replicates (flasks) and each flask contained two spikes. After standardization, $4 \mathrm{mM} \mathrm{SPM}$, $6 \mathrm{mM}$ PUT and $6 \mathrm{mM}$ SPD were found to be optimum concentrations for improving various postharvest attributes. The concentrations above and below the optimum concentrations were less effective in improving various postharvest attributes. The oldest buds present on the spikes were used for analysis of various biochemical parameters (activity of antioxidant enzymes SOD, APX and CAT, LOX activity, total protein, total sugars and phenols) on day 2 and day 5 of transfer into test solutions. The day of transfer was designated as day zero. The effects of treatments were observed by keeping the spikes in laboratory under cool white fluorescent light with a mix of diffused natural light $\left(10 \mathrm{~W} \mathrm{~m}^{-2}\right) 12-\mathrm{h}$ per day, at a temperature of $22 \pm 2{ }^{\circ} \mathrm{C}$ and $\mathrm{RH}$ of $60 \% \pm 10 \%$.

\section{Assessment of vase life and floral diameter}

The average vase life of the spikes was counted from the day 1 and was assessed to be terminated when approximately $70 \%$ florets senesced on each spike. The experiment was maintained till the vase life in the last set of spikes was regarded to be terminated. The floral diameter was measured on day 2 and 5 as the mean of two perpendicular measurements across the flower.

\section{Membrane stability index (MSI)}

The membrane leakage was estimated by incubating $500 \mathrm{mg}$ tepal tissue in $25 \mathrm{~mL}$ of deionized water at 25 ${ }^{\circ} \mathrm{C}$ for $30 \mathrm{~min}$ and at $100{ }^{\circ} \mathrm{C}$ for $15 \mathrm{~min}$ (Sairam, 1994). The conductivity of the samples incubated at $25^{\circ} \mathrm{C}$ was designated as $\mathrm{C} 1$ and those incubated at $100{ }^{\circ} \mathrm{C}$ was designated as $\mathrm{C} 2$ after recording the values on Elico CM180 Conductivity meter. MSI was computed as:

$$
\mathrm{MSI}=[1-\mathrm{C} 1 / \mathrm{C} 2] \times 100
$$

\section{Protein estimation}

Estimation of Soluble proteins was performed by Lowry et al. (1951) method using bovine serum albumin (BSA) as standard.

\section{Estimation of sugars and phenols}

One $\mathrm{g}$ of chopped tepal tissue was fixed in $70 \%$ hot ethanol from each treatment. The tissue was later macerated and centrifuged thrice. The supernatants were filtered out and used for the quantification of sugars, amino acids and total phenols. Reducing sugars were determined by Nelson's method (1944) using glucose as a standard. Total sugars were estimated by converting non-reducing sugars to reducing sugars using invertase. The quantity of non-reducing sugars was calculated as difference between total and reducing sugars. Estimation of total phenolics was carried by Swain and Hillis method (1959) with gallic acid as standard.

\section{Enzyme assays}

\section{Superoxide dismutase (SOD)}

One $\mathrm{g}$ tepal tissue was homogenized in $0.1 \mathrm{mM}$ potassium phosphate buffer $(\mathrm{pH} 7.8)$ containing $0.1 \mathrm{mM}$ ethylenediaminetetraacetic acid (EDTA), 1\% PVP and $0.5 \%(\mathrm{v} / \mathrm{v})$ Triton X-100. The homogenate was centrifuged for 10 minutes at $15,000 \times \mathrm{g}$. The supernatant was pooled and employed for the enzyme assay. The Dhindsa et al. method (1981) was employed to quantify superoxide dismutase (SOD) activity by monitoring the inhibition of photochemical reduction of nitro blue tetrazolium (NBT). 
The reaction mixture contained $75 \mu \mathrm{M}$ NBT, $50 \mathrm{mM}$ sodium carbonate, $0.1 \mathrm{mM}$ EDTA, $13 \mathrm{mM}$ methionine in $50 \mathrm{mM}$ phosphate buffer $(\mathrm{pH} 7.8)$ and $0.1 \mathrm{~mL}$ of the enzyme extract in a final volume of $3 \mathrm{~mL}$. The reaction was started by adding $1 \mu \mathrm{M}$ riboflavin and placing the test tubes in water bath at $25^{\circ} \mathrm{C}$ and illuminating with a $30 \mathrm{~W}$ fluorescent lamp. The reaction was stopped by switching off the light and keeping the test tubes in darkness. Identical test tubes which were not illuminated served as blanks. Absorbance was measured at $560 \mathrm{~nm}$ and one unit of SOD activity was defined as the quantity of the enzyme that inhibits the photo reduction of NBT to blue formazan by $50 \%$ as compared to the reaction mixture kept in dark without the enzyme extract. The SOD activity was expressed as units $\min ^{-1} \mathrm{~g}^{-1}$ fresh mass.

\section{Ascorbate peroxidase (APX)}

APX activity was determined by mashing the tepal tissues in $100 \mathrm{mM}$ sodium phosphate buffer containing 1mM EDTA, $5 \mathrm{mM}$ Ascorbate and $10 \%$ glycerol. The APX activity was estimated in $1 \mathrm{~mL}$ reaction mixture containing $0.3 \mathrm{mM} \mathrm{H}_{2} \mathrm{O}_{2}$, $50 \mathrm{mM}$ potassium phosphate buffer $(\mathrm{pH}=7.0)$ and $0.1 \mathrm{mM}$ Ascorbate. The decrease in the absorbance was noted at $290 \mathrm{~nm}$ for $3 \mathrm{~min}$ (Chen and Asada 1989).

\section{Catalase (CAT)}

Activity of Catalase was measured by Aebi's method (1984). One g of tepal tissue was mashed and homogenized in $100 \mathrm{mM}$ potassium phosphate buffer $(\mathrm{pH}=7.0)$ containing $1 \mathrm{mM}$ EDTA. The reaction mixture contained $50 \mu$ l enzyme extract, $50 \mathrm{mM}$ potassium phosphate buffer $(\mathrm{pH}=7.0), 12.5 \mathrm{mM} \mathrm{H}_{2} \mathrm{O}_{2}$, and distilled water to make the volume to $3 \mathrm{~mL}$. Reaction was initiated by addition of $\mathrm{H}_{2} \mathrm{O}_{2}$ and the activity of catalase was estimated by the consumption of $\mathrm{H}_{2} \mathrm{O}_{2}$ for $3 \mathrm{~min}$ at $240 \mathrm{~nm}$ and was expressed as $\mu \mathrm{mol} \mathrm{H}_{2} \mathrm{O}_{2}$ red. $\mathrm{min}^{-1} \mathrm{mg}^{-1}$.

\section{Lipoxygenase (LOX)}

Axelrod et al. method (1981) was employed to determine LOX activity. One g tepal tissue was mashed in $1 \mathrm{ml}$ extraction buffer containing $50 \mathrm{mM}$ potassium phosphate buffer $(\mathrm{pH}=6.5), 10 \%$ polyvinyl pyrrolidone (PVP), $1 \mathrm{mM}$ phenyl methyl sulfonyl fluoride (PMSF) and $0.25 \%$ Triton $\mathrm{X}-100$. The reaction mixture $(1 \mathrm{~mL})$ contained $50 \mathrm{mM}$ Tris- $\mathrm{HCl}$ buffer $(\mathrm{pH}=6.5)$ and $0.4 \mathrm{mM}$ linoleic acid. The reaction was started by adding $10 \mu \mathrm{L}$ crude tepal extract to the reaction mixture and absorbance was recorded at $234 \mathrm{~nm}$ for $5 \mathrm{~min}$.

\section{Experimental design and data analysis}

The experiment was performed by using completely randomized design and the treatment means were compared by ANOVA (analysis of variance). The significant differences among the treatments were determined by using Duncan's test $(p<0.05)$. The statistical analysis was performed through SPSS software (SPSS version 16; Chicago, USA).

\section{Results}

\section{Vase life and floral diameter}

Vase life was significantly improved in all the polyamine treated spikes as compared to control (Figure 1). The maximum increase in vase life (13 days) was achieved by application of $4 \mathrm{mM}$ SPM as compared to 7 days in control. The vase life of spikes treated with $6 \mathrm{mM}$ PUT and $6 \mathrm{mM}$ SPD was extended to 10.2 and 9 days respectively. Besides vase life, the flower diameter also showed a gradual increase in polyamine treated spikes with maximum increase $(3.5 \mathrm{~cm})$ observed in SPM treated spikes. Moreover, the floral diameter exhibited a gradual decline with the advancement in time from day 2 to day 5 (Figures 2A and 2B). 

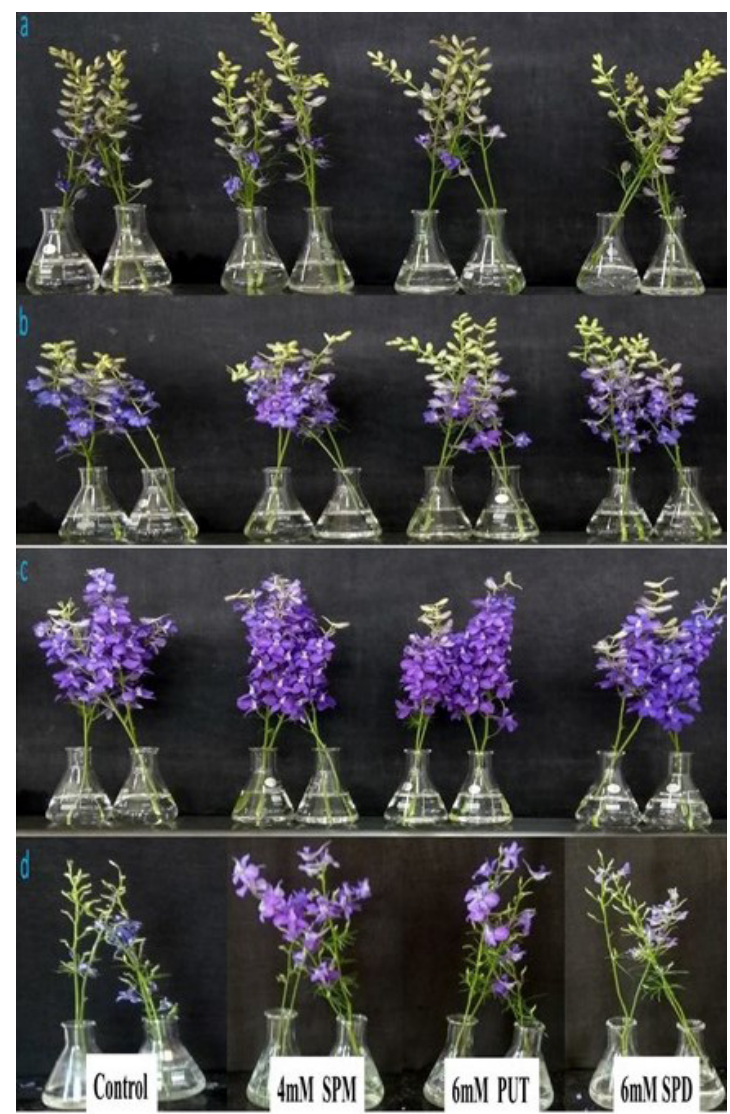

Figure 1. Effect of various polyamines on vase life and flower quality of cut spikes of C. ajacis on day 0 (a), day 2 (b), day 5 (c), and day $11(\mathrm{~d})$ of transfer of spikes to respective test solutions

\section{A}

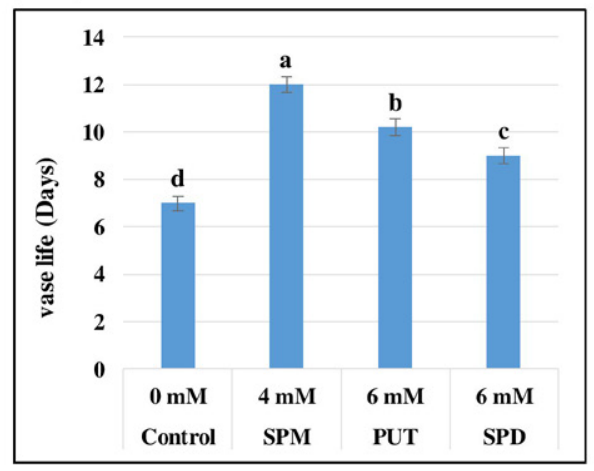

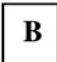

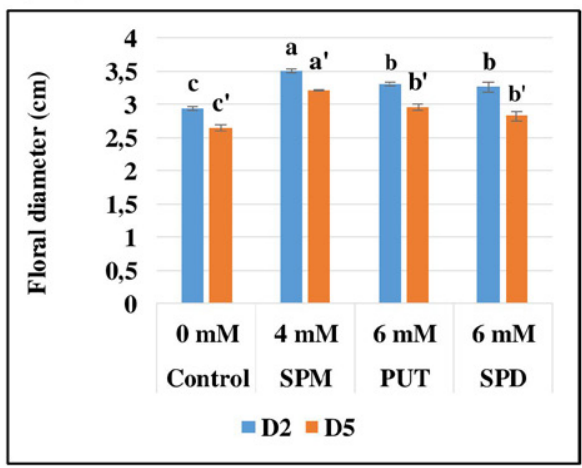

Figure 2. Effect of various polyamines on vase life (A) and floral diameter (B) of C. ajacis cut spikes. Each value is a mean of 3 replicates. Letters from (a-d) above the bars represent the statistical significance between different treatments. Only bars with different letters are statistically significant at $(\mathrm{p}<0.05)$.

Membrane stability index (MSI) and Lipoxygenase activity (LOX)

Membrane integrity was profoundly improved in polyamine treated tepal tissues as compared to control. Maximum MSI values were recorded in SPM treated tepal tissues followed by PUT and SPD. However, the improvement in membrane integrity was concomitant with decrease in LOX activity, with maximum decrease observed in SPM treated tepal tissues. Decrease in LOX activity due to polyamine application reduced membrane seepage and improved membrane stability (Figures 3A and $3 \mathrm{~B})$. 


\section{$\mathbf{A}$}

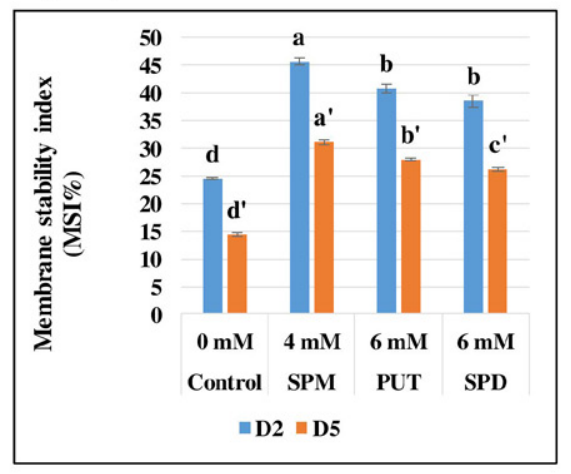

\section{B}

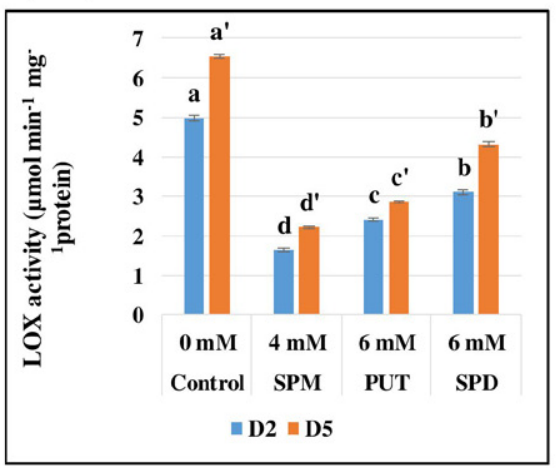

Figure 3. Effect of various polyamines on MSI (A) and LOX activity (B) of C. ajacis cut spikes. Each value is a mean of 3 replicates. Letters from (a-d) above the bars represent the statistical significance between different treatments.

Only bars with different letters are statistically significant at $(\mathrm{p}<0.05)$.

\section{Soluble proteins}

The progression in senescence process involves decline in soluble proteins due to upsurge in protease activity. However, the concentration of soluble proteins was found to be higher in polyamine treated floral tissues as compared to control (Figure 4). Among the different polyamine treatments, SPM was found to effective in curtailing protein breakdown as compared to PUT and SPD. Furthermore, a decline was recorded in protein content of tepal tissues at later stages of the experiment.

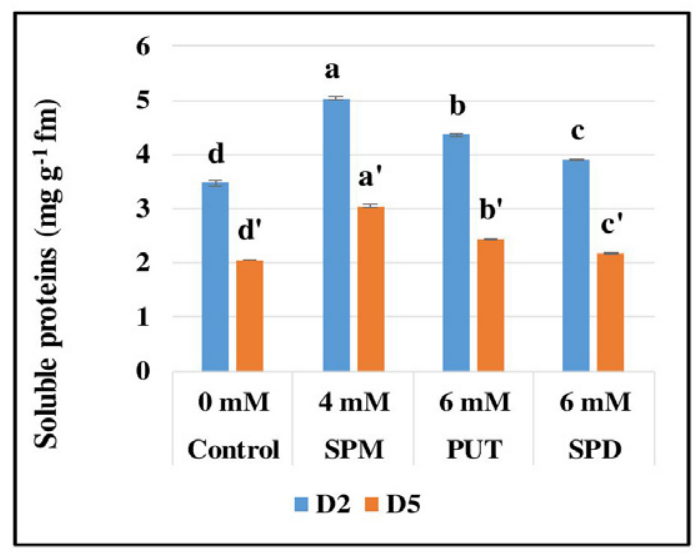

Figure 4. Effect of various polyamines on soluble proteins of $C$. ajacis cut spikes. Each value is a mean of 3 replicates. Letters from (a-d) above the bars represent the statistical significance between different treatments.

Only bars with different letters are statistically significant at $(\mathrm{p}<0.05)$.

\section{Total Sugars and phenols}

Application of polyamines caused a profound enrichment of sugars and phenols in tepal tissues as compared to control. Maximum accumulation of sugars and phenols was promoted by SPM followed by PUT and SPD (Figures 5A-D). Enrichment in sugar and phenolic content of tepal tissues provides energy reserves to floral tissues and reinforces the antioxidant system to scavenge free radicals to mitigate postharvest senescence. 
A

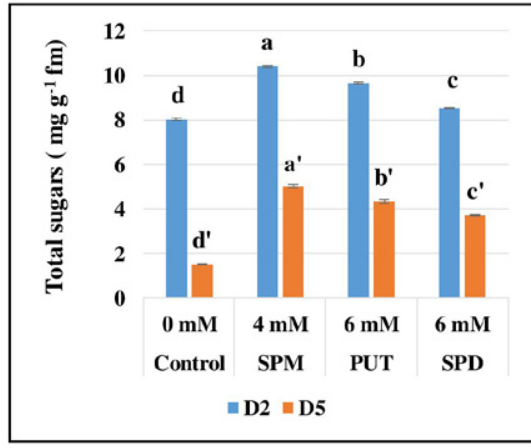

c

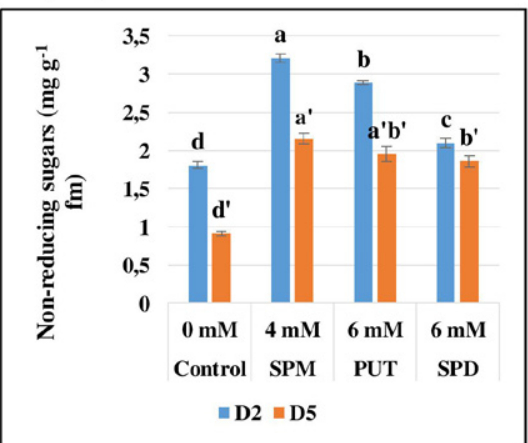

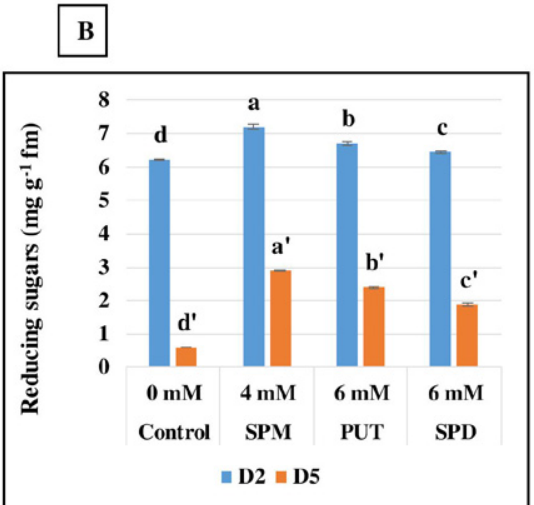
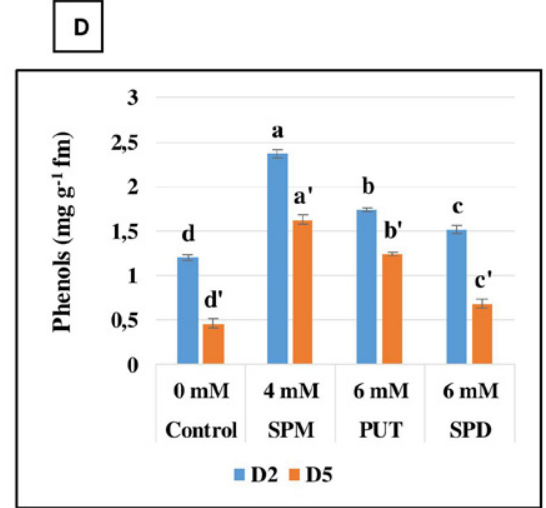

Figure 5. Effect of various polyamines on total sugars (A), reducing sugars (B), non- reducing sugars (C) and phenols (D) of C. ajacis cut spikes. Each value is a mean of 3 replicates. Letters from (a-d) above the bars represent the statistical significance between different treatments. Only bars with different letters are statistically significant at $(\mathrm{p}<0.05)$.

\section{Antioxidant enzymes}

The changes in the activity of various antioxidant enzymes (SOD, CAT and APX) during different stages of experiment are reflected in (Figures 6A-C). During the present study application of polyamines particularly $4 \mathrm{mM}$ SPM resulted in considerable upsurge in the activity of various antioxidant enzymes as compared to control. These antioxidant enzymes neutralized the ROS (reactive oxygen species) production and improved the vase performance of cut spikes. However, the activity of these antioxidant enzymes exhibited a steady decline towards later stages of the experiment. 

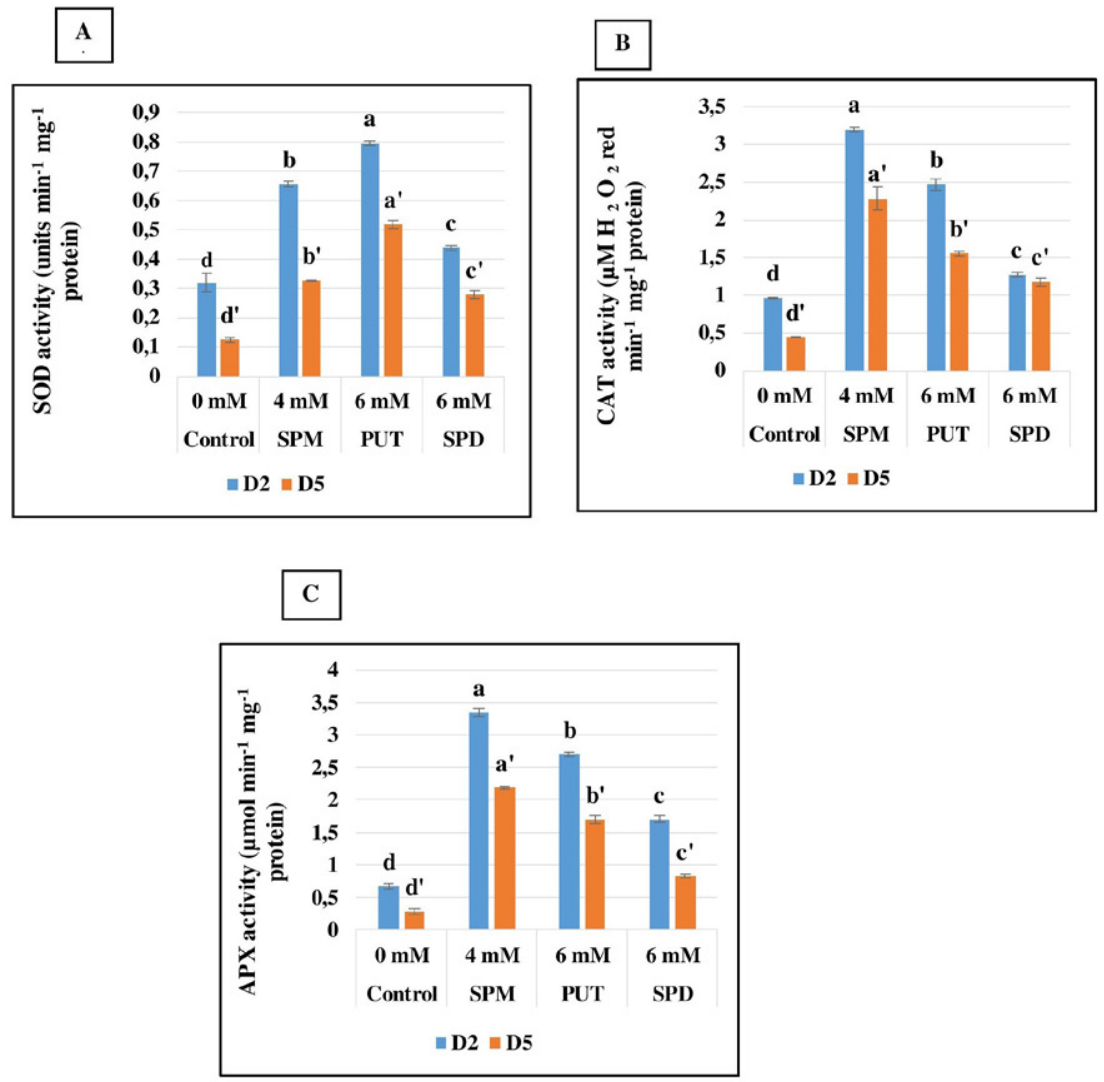

Figure 6. Effect of various polyamines on SOD (A), CAT (B) and APX (C) activity of C. ajacis cut spikes. Each value is a mean of 3 replicates. Letters from (a-d) above the bars represent the statistical significance between different treatments. Only bars with different letters are statistically significant at $(\mathrm{p}<0.05)$.

\section{Discussion}

Based on the results, we justify considerable role of polyamines in mitigating postharvest losses in cut flowers through improvement in various postharvest attributes. Our findings indicate a significant improvement in vase life of C. ajacis spikes due to polyamine treatments. The extension in vase life may be correlated with the upsurge in activity of various antioxidant enzymes besides, maintaining higher content of sugars and proteins in tepal tissues (Ahmad and Tahir, 2018). Moreover, decrease in membrane seepage due to polyamine application has also been found to be associated with flower longevity as reported in cut rose flowers (Ghorbani et al., 2018). Polyamine mediated increase in vase life has been also reported in Rosa hybrida, Nicotiana plumbaginifolia and Dianthus caryophyllus (Nisar et al., 2015; Vieira et al., 2017; Karimi et al., 2017). The floral diameter also registered an increase in polyamine treated spikes. Increase in floral diameter could be attributed to enrichment of carbohydrates in tepal tissues which facilitate osmotic inflow of water thereby increasing floral diameter (Reid and Wu, 2018; Lone at al., 2021).

Membrane integrity is also recognized as key factor central to the vase life of cut flowers. Increased membrane leakiness due to upsurge in lipoxygenase activity is one of the key events during senescence of various flowers like Iris and Clarkia (Ahmad and Tahir, 2016; Dar et al.,
2020). Application of various polyamines significantly improved the membrane stability index. The increase in MSI values corroborated with the corresponding decrease in LOX activity due to different polyamine treatments. In agreement to our results, similar findings were reported in Iris germanica and Rosa hybrida (Danaee and Abdossi, 2018; Ahmad and Tahir, 2018). Polyamines bind to membrane phospholipids to prevent their peroxidation (Mohammadi et al., 2018). Polyamines reduce membrane outflow by attenuating LOX activity thereby improving flower quality (Yousefi et al., 2019).

Proteolysis is recognized as key step during onset of flower senescence as reported in Rosa (Lu et al., 2019). Treatment with polyamines maintained higher concentration of soluble proteins in the tepal tissues as compared to untreated ones. Increase in protein content due to polyamine application has also been reported in Anthurium, and Paeonia (Han et al., 2018; Simões et al., 2018). The increase in protein content of tepal tissues could be due to down regulation of protease activity and stabilization of proteins through binding of amine group $\left(\mathrm{NH}_{2}\right)$ of polyamines to carboxylic group $(\mathrm{COOH})$ of proteins. (Nisar et al., 2015; Ahmad and Tahir 2018). Moreover, proteins serve as alternate energy reserves and reduce starvation effect of sugars (Hirota et al., 2018). In addition, protein enrichment reinforces stress specific defense systems through amplification of antioxidant enzyme activity and synthesis of stress related proteins, 
thereby delaying onset of senescence (Doganlar et al., 2010; Promyou et al., 2012).

Application of polyamines to cut spikes of $C$. ajacis resulted in accumulation of higher phenolic content in tepal tissues as compared to control. Recent studies conducted in Anthurium and Gerbera flowers also substantiate considerable role of polyamines in phenolic enrichment of their petal tissues (Simões et al., 2018; Mohammadi et al., 2020). Polyamines trigger the activity of phenylalanine ammonia-lyase enzyme (PAL) which promote synthesis of phenolic substances and improve flower quality by maintaining color of petal tissues (Tanaka et al., 2008; Danaee and Abdossi, 2018). Phenolic compounds bind to polar heads of membrane phospholipids inside and outside and shield them from oxidative damage due to ROS (Mohammadi et al., 2020). Pertinently, polyamines act to reduce activity of polyphenol oxidase to prevent oxidation of phenolic compounds which otherwise causes browning of floral tissues (Mohammadi et al., 2020).

Sugars act as important energy reserves for cut flowers and preserve their quality by preventing membrane leakage and wilting of petal tissues (Pérez-Arias et al., 2019). Generally, the onset of senescence is characterised by decline in sugar content as a result of oxidative process (Cavasini et al., 2018). Whereas, exogenous inclusion of polyamines retained higher concentration of sugars in tepal tissues as compared to control. Maintenance of higher sugar content in tepal tissues by polyamines may be attributed to regulated consumption of sugars through decrease in cellular respiration (Nisar et al., 2015; Ahmad and Tahir, 2018). Sugars maintain petal coloration through synthesis of anthocyanins and retain water content in petal tissues through osmotic regulation (Hemati et al., 2019). Higher sugar content in petal tissues has been found to improve flower longevity in various flower systems like Calendula and Nicotiana (Lone et al., 2021; Nisar et al., 2021).

Detachment of flowers from the mother plant leads to their quality deterioration due to senescence (Ewa et al., 2020). Pertinently, application of polyamines to cut spikes of $C$. ajacis augmented their antioxidant capacity through increased activity of antioxidant enzymes (SOD, CAT and APX). These antioxidant enzymes alleviate the oxidative stress through ROS elimination and minimize membrane damage to avert deterioration of flower quality (Lone et al., 2021). Upsurge in activity of antioxidant enzymes due to polyamine treatments has been also reported in flowers such as Anthurium and Gerbera (Simões et al., 2018; Mohammadi et al., 2020).

\section{Conclusions}

The present research suggests the explicit role of polyamines in alleviating postharvest senescence in cut spikes of $C$. ajacis. The application of polyamines improved the vase life by reinforcing the antioxidant capacity and maintained higher content of protein and sugars in tepal tissues. Spermine was found to be most effective postharvest treatment to prolong vase life of $C$. ajacis flowers. Moreover, our study reveals the intricate mechanisms of polyamines in relation to flower senescence yet undertaking molecular studies to unravel the detailed mechanism of polyamine action would greatly bridge the knowledge gaps. Besides, monitoring petal water content and ethylene levels, understanding the crosstalk of polyamines with ethylene and other growth regulators would enable us to formulate ecofriendly and cost-effective postharvest treatments to facilitate efficient marketing of cut flowers with huge economic implications.

\section{Author Contribution}

AUH: performed experiments, obtained results, took photographs, compiled the data and drafted the manuscript; IT: helped in designing the experiment, supervised the laboratory work, and edited the manuscript; MLL, SF, FA, SP: helped in statistical analysis of the data and in the laboratory work.

\section{Acknowledgments}

The authors thank Head Department of Botany for providing necessary facilities. Besides, the authors acknowledge all senior scholars of Plant Physiology and Biochemistry laboratory for the insights conveyed.

\section{References}

AEBI, H. Catalase in vitro. Methods in Enzymology, v.105, p.121-126, 1984. https://doi.org/10.1016/s00766879 (84)05016-3

AHMAD, S.S.; TAHIR, I. Increased oxidative stress, lipid peroxidation and protein degradation trigger senescence in Iris versicolor L. flowers. Physiology and Molecular Biology of Plants, v.22, n.4, p.507-514, 2016. https://doi. org/10.1007/s12298-016-0392-9

AHMAD, S.S.; TAHIR, I. Putresine and jasmonates outplay conventional growth regulators in improving postharvest performance of Iris germanica L. cut scapes. Proceedings of the National Academy of Sciences, India Section B: Biological Sciences, v. 88, p.391-402, 2018. https://doi. org/10.1007/s12298-018-0554-z

ATAII, D.; NADERI, R.; KHANDAN-MIRKOHI, A. Exogenous putrescine delays senescence of Lisianthus cut flowers, Journal of Ornamental Plant, v.5, n.3, p.167$174,2015$.

AXELROD, B.; CHESBROUGH T.M.; LAAKSO, S. Lipoxygenase from soybean. In: LOWENSTEIN, J.M. (Ed.). Methods in Enzymology. New York: Academic Press, 1981. p.441-451.

CAVASINI, R.; LASCHI, D.; TAVARES, A.R.; LIMA, G.P.P. Carbohydrate reserves on postharvest of Lisianthus cut flowers. Ornamental Horticulture, v.24, p.12-18, 2018. 
CHEN, G.X.; ASADA, K. Ascorbate peroxidase in tea leaves: occurrence of two isozymes and the differences in their enzymatic and molecular properties. Plant Cell Physiology, v.30, p.987-998, 1989. https://doi.org/10.1093/ oxfordjournals.pcp.a077844

DANAEE, E.; ABDOSSI, V. Effect of different concentration and application methods of polyamines (putrescine, spermine, spermidine) on some morphological, physiological, and enzymatic characteristics and vase life of Rosa hybrida cv. 'Dolce Vita' cut flower. Journal of Ornamental Plants, v.8, n.3, p.171-182, 2018.

DAR, R.A.; NISAR, S.; TAHIR, I. Alleviation of antioxidant enzyme activity by an hour $0.25 \mathrm{~mm}$ silver thiosulphate pulse duration in Clarkia amoena. Proceedings of the National Academy of Sciences, India Section B: Biological Sciences, v.90, p.47-53, 2020. https://doi.org/10.1007/s40011-019-01079-9

DAVARYNEJAD, G.H.; NURZADEHNAMAGHI, M.; MOMEN, A. Evaluation of the effect of exogenous application of polyamines on growth, nut traits and yield of 'Akbari'Pistachio trees (Pistacia vera L.). Journal of Horticultural Science, v.34, p.547-561, 2021. https://doi. org/10.22067/JHORTS4.V34I4.75961

DHINDSA, R.S.; PLUMB-DHINDSA, D.; THORPE, T.A. Leaf senescence: correlated with increased levels of membrane permeability and lipid peroxidation, and decreased levels of superoxide dismutase and catalase. Journal of Experimental Botany v.32, p.93-101, 1981. https://doi.org/10.1093/jxb/32.1.93

DOGANLAR, Z.B.; DEMIR, K.; BASAK, H.; GUL, I. Effects of salt stress on pigment and total soluble protein contents of three different tomato cultivars. African Journal of Agricultural Research, v.5, p.2056-2065, 2010.

EWA, S.; AGATA, J.; JULITA, R.Ś.; JULIA, R.W.; MONIKA, L.; ALEKSANDRA, Ł. Nanosilver as a novel biocide for control of senescence in garden Cosmos. Scientific Reports, v.10. n.1, 2020. https://doi. org/10.1038/s41598-020-67098-z

GHORBANI, H.; EBRAHIMZADEH, A.; EFTEKHARI SIS, B.; HASANPOURAGHADM, M.B. Impact of exogenous spermine application on the vase life of cut rose flowers 'Dolce Vita'. Journal of Ornamental Plants, v.8, n.1, p.57-66, 2018.

HA, S.T.T.; IN, B.C.; CHOI, H.W.; JUNG, Y.O.; LIM, J.H. Assessment of pretreatment solutions for improving the vase life and postharvest quality of cut roses (Rosa hybrida L.'Jinny'). Flower Research Journal v. 25, p.101-109, 2017.

HAN, L.; SUN, X.; XU, J.G.; LI, Q.; GAO, C.R.; LU, J.; DU, G.C. The influence of polyamine and polyamine inhibitors in herbaceous peony postharvest physiology. Indian Journal of Plant Physiology, v.23, n.3, p.499-506, 2018.
HEMATI, E.; SALEHI SALMI M.R.; DANESHVAR M.H.; HEIDARI, M. The roles of sodium nitroprusside, salicylic acid, and methyl jasmonate as hold solutions on vase life of Gerbera jamesonii 'Sun Spot'. Advances in Horticultural Science, v.33, n.2, p.187-195, 2019.

HIROTA, T.; IZUMI, M.; WADA, S.; MAKINO, A.; ISHIDA, H. Vacuolar protein degradation via autophagy provides substrates to amino acid catabolic pathways as an adaptive response to sugar starvation in Arabidopsis thaliana. Plant and Cell Physiology, v.59, n.7, p.13631376, 2018. https://doi.org/10.1093/pcp/pcy005

IQBAL, N.; KHAN, N.A.; FERRANTE, A.; TRIVELLINI, A.; FRANCINI, A.; KHAN, M.I.R. Ethylene role in plant growth, development and senescence: interaction with other phytohormones. Frontiers in Plant Science, v.8, p.475, 2017. https://doi.org/10.3389/fpls.2017.00475

KARIMI, M.; AKBARI, F.; HEIDARZADE, A. Protective effects of polyamines on regulation of senescence in spray carnation cut flowers (Dianthus caryophyllus 'Spotlight'). Acta Agriculturae Slovenica, v.109, n.3, p.509515, 2017. https://doi.org/10.14720/aas.2017.109.3.03

KANDIL, M.M.; EL-SAADY, M.B.; MONA, H.M.; AFAF, M.H.; IMAN, M.E. Effect of Putresine and uniconazole treatments on flower characters and photosynthetic pigments of Chrysanthemum indicum L. American Journal of Plant Science, v.7, n.3, p.399-408, 2011.

LONE, M.L.; FAROOQ, S.; PARVEEN, S.; TAHIR, I. 6-Benzylamino purine outperforms Kinetin and Thidiazuron in ameliorating flower longevity in Calendula officinalis L. by orchestrating physiological and biochemical responses. Ornamental Horticulture, v.27, n.2, p.183-195, 2021. https://doi.org/10.1590/2447-536X.v27i2.2260

LOWRY, O.H.; ROSEBROUGH. N.J.; FARR, A.L.; RANDALL, R.J. Protein measurement with the Folin phenol reagent. Journal of Biological Chemistry, v.19, p.265-275, 1951. https://doi.org/10.1016/s0021-9258 (19)52451-6

LU, J.; XU, Y.; FAN, Y.; WANG, Y.; ZHANG, G.; LIANG, Y.; MA, C. Proteome and ubiquitome changes during rose petal senescence. International Journal of Molecular Sciences, v.20, n.24, p.6108, 2019. https://doi.org/10.3390/ ijms20246108

MA, N.; MA, C.; LIU, Y.; SHAHID, M.O.; WANG, C.; GAO, J. Petal senescence: a hormone view. Journal of Experimental Botany, v.69, n.4, p.719-732, 2018. https:// doi.org/10.1093/jxb/ery009

MOHAMMADI, H.; GHORBANPOUR, M.; BRESTIC, M. Exogenous putrescine changes redox regulations and essential oil constituents in feld-grown Tymus vulgaris L. under well-watered and drought stress conditions. Industrial Crops and Products, v.122, p.119-132, 2018. 
MOHAMMADI, M.; AELAEI, M.; SAIDI, M. Pre-harvest and pulse treatments of spermine, $\gamma$-and $\beta$-aminobutyric acid increased antioxidant activities and extended the vase life of Gerbera cut flowers 'Stanza'. Ornamental Horticulture, v.26, n.2, p.306-316, 2020. https://doi. org/10.1590/2447-536x.v26i2.2120.

NELSON, N.A. photometric adaptation of the Somogyi method for the determination of glucose. Journal of Biological Chemistry, v.153, p.375-380, 1944. https://doi. org/10.1016/s0021-9258(18)71980-7

NISAR, S., TAHIR, I.; AHMAD, S.S. Modulation of flower senescence in Nicotiana plumbaginifolia L. by polyamines. Indian Journal of Plant Physiology, v.20, n.2, p.186-190, 2015. https://doi.org/10.1007/s40502-015-0154-7

NISAR, S.; DAR, R.A.; TAHIR, I. Salicylic acid retards senescence and makes flowers last longer in Nicotiana plumbaginifolia (Viv). Plant Physiology Reports, p.1-9, 2021

PÉREZ-ARIAS, G.A.; ALIA-TEJACAL, I.; COLINASLEÓN, M.T.; VALDEZ-AGUILAR, L.A.; PELAYOZALDÍVAR, C. Postharvest physiology and technology of the tuberose (Polianthes tuberosa L.): an ornamental flower native to Mexico. Horticulture, Environment and Biotechnology, p.1-13, 2019.

PROMYOU, S.; KETSA, S.; VAN DOORN, W.G. Salicylic acid alleviates chilling injury in anthurium (Anthurium andraeanum L.) flowers. Postharvest Biology and Technology, v.64, p.104-110, 2012. https://doi. org/10.1016/j.postharvbio.2011.10.002.

RABIZA-ŚWIDER, J.; SKUTNIK, E.; JĘDRZEJUK, A.; ŁUKASZEWSKA, A. Postharvest treatments improve quality of cut peony flowers. Agronomy, v.10, n.10, p.1583, 2020. https://doi.org/10.3390/agronomy10101583.

REID, M.S.; WU, M.J. Ethylene in flower development and senescence. In: MATTOO, A.K.; SUTTLE, J.C. (Ed.). The plant hormone ethylene. Boca Raton: CRC Press Taylor and Francis Group, 2018. p.4-32.

SAIRAM, R.K. Effect of moisture stress on physiological activities of two contrasting wheat genotypes. Indian Journal of Experimental Biology, v.32, p.584-593, 1994. https://doi.org/10.1007/bf00025220.

SEDAGHATHOOR, S.; NAROUEI, Z.; SAJJADI, S. A.; PIRI, S. The effect of chemical treatments (silver thiosulfate and putrescine) on vase life and quality of cut Chrysanthemum morifolium (Ram.) flowers. Cogent Biology, v.6, n.1, p.1754320, 2020. https://doi.org/10.108 0/23312025.2020.1754320.
SHAHRI, W.; I. TAHIR. Comparative effect of ethylene antagonists: Silver thiosulphate (STS) and Amino-oxyacetic acid (AOA) on postharvest performance of cut spikes of Consolida ajacis cv. Violet. International Journal of Agriculture Food Science and Technology, v.1, n.2, p.103113, 2010. https://doi.org/10.1007/s13580-011-0229-y

SHAHRI, W.; TAHIR, I.; ISLAM, S.T.; BHAT, M.A. Synergistic effect of STS and cool storage on postharvest performance of cut spikes of Consolida ajacis cv. violet blue. Horticulture, Environment and Biotechnology, v.52, n.5, p.466-470, 2011.

SIMÕES, A.N.; DINIZ, N.B.; VIEIRA, M.R.S.; SILVA, S.L.F.; SILVA, M.B.; MINATEL, I.O.; LIMA, G.P.P. Impact of $\mathrm{GA}_{3}$ and spermine on postharvest quality of anthurium cut flowers (Anthurium andraeanum) cv. Arizona. Scientia Horticulturae, p.178-186, 2018. https://doi.org/10.1016/j. scienta.2018.06.095

SWAIN, T.; HILLIS, W.E. The phenolic constituents of Prunus domestica I. The quantitative analysis of phenolic constituents. Journal of Science Food and Agriculture. v.10, p. 63-68, 1959. https://doi.org/10.1002/jsfa.2740100110.

TANAKA, Y.; SASAKI, N.; OHMIYA, A. Biosynthesis of plant pigments: anthocyanins, betalains and carotenoids. Plant Journal, v.54, p.733-749, 2008. https://doi. org/10.1111/j.1365-313X.2008.03447.x

TIBURCIO, A.F; ALTABELLA, T.; BITRIÁN, M.; ALCÁZAR, R. The roles of polyamines during the lifespan of plants: from development to stress. Planta, v.240, n.1, p.1-18, 2014. https://doi.org.101007/s00425-014-2055-9

VEHNIWAL, S.S.; ABBEY, L. Cut flower vase lifeinfluential factors, metabolism and organic formulation. Journal of Horticulture, v.3, n.6, p.275-281, 2019. https:// doi.org.10.15406/hij.2019.03.00142

VIEIRA, M.R.S.; MOURA, F.B.; SIMÕES, A.D.N.; SOUZA, A.V.; SANTOS, C.M.; PAES, R.D.A.; LEAL, Y.H. Application of polyamine and boron improves quality of potted Gerbera cv. 'Kosak'. Journal of Applied Horticulture, v.19, n.1, p.84-88, 2017.

YOUSEFI, F.; JABBARZADEH,Z.;AMIRI, J.; RASOULISADAGHIANI, M.H. Response of roses (Rosa hybrida L. 'Herbert Stevens') to foliar application of polyamines on root development, flowering, photosynthetic pigments, antioxidant enzymes activity and NPK. Scientific Reports, v.9, n.1, p.1-11, 2019. 